\title{
Coastal inundation and damage exposure estimation: a case study for Jakarta
}

\author{
P. J. Ward • M. A. Marfai · F. Yulianto - D. R. Hizbaron • \\ J. C. J. H. Aerts
}

Received: 26 March 2010/Accepted: 9 August 2010/Published online: 31 August 2010

(C) The Author(s) 2010. This article is published with open access at Springerlink.com

\begin{abstract}
Coastal flooding poses serious threats to coastal areas, and the vulnerability of coastal communities and economic sectors to flooding will increase in the coming decades due to environmental and socioeconomic changes. It is increasingly recognised that estimates of the vulnerability of cities are essential for planning adaptation measures. Jakarta is a case in point, since parts of the city are subjected to regular flooding on a near-monthly basis. In order to assess the current and future coastal flood hazard, we set up a GIS-based flood model of northern Jakarta to simulate inundated area and value of exposed assets. Under current conditions, estimated damage exposure to extreme coastal flood events with return periods of 100 and 1,000 years is high (€4.0 and $€ 5.2$ billion, respectively). Under the scenario for 2100, damage exposure associated with these events increases by a factor 4-5, with little difference between low/high sea-level rise scenarios. This increase is mainly due to rapid land subsidence and excludes socioeconomic developments. We also develop a detemporalised inundation scenario for assessing impacts associated with any coastal flood scenario. This allows for the identification of critical points above which large increases in damage exposure can be expected and also for the assessment of adaptation options against hypothetical user-defined levels of change, rather than being bound to a discrete set of a priori scenarios. The study highlights the need for urgent attention to the land subsidence problem; a continuation of the current rate would result in catastrophic increases in damage exposure.
\end{abstract}

Keywords Flood · Damage $\cdot$ Jakarta $\cdot$ GIS $\cdot$ Model

P. J. Ward $(\bowtie)$. J. C. J. H. Aerts

Institute for Environmental Studies (IVM), Faculty of Earth and Life Sciences, VU University

Amsterdam, De Boelelaan 1085, 1081 HV Amsterdam, The Netherlands

e-mail: philip.ward@ivm.vu.nl

M. A. Marfai · D. R. Hizbaron

Faculty of Geography, Gadjah Mada University, Yogyakarta, Indonesia

F. Yulianto

Remote Sensing Application and Technology Development Center, Indonesian National Institute of Aeronautics and Space (LAPAN), Jakarta, Indonesia 


\section{Introduction}

Coastal flooding poses serious threats to coastal areas around the world, billions of dollars in damage to property and infrastructure, and threatens the lives of millions of people (Dasgupta et al. 2009; Nicholls 2004; Nicholls et al. 2008). The vulnerability of coastal communities and economic sectors to coastal flooding is expected to increase in the coming decades to century due to both environmental and socioeconomic changes (IPCC 2007a; Rosenzweig and Solecki 2001). Firstly, global sea-level rise will lead to an increase in flood hazard in coastal regions (IPCC 2007a). Secondly, many coastal and deltaic areas suffer from land subsidence due to a combination of glacial-isostatic adjustments (e.g. Peltier 1998), natural subsidence in deltaic areas (e.g. Meckel et al. 2007), and human activities (e.g. Chatterjee et al. 2006; Ericson et al. 2006; Nicholls 1995; Nicholls et al. 2007, 2008). A third environmental factor is the possible increase in peak wind intensities as a result of climate change (IPCC 2007b), which may lead to increased storm surge heights in some regions (Nicholls et al. 2008). Finally, the vulnerability of coastal cities will also increase due to socioeconomic trends such as the continued demographic and economic expansion in these areas (Bouwer et al. 2007).

Given the scale of these problems, it is increasingly recognised that estimates of the vulnerability of cities are essential in the planning of adaptation measures (Aerts et al. 2009). The work of Nicholls et al. (2008) made an important contribution to this process, providing a first estimate of the exposure of 136 port cities (with populations above one million) to coastal flooding and examining how this exposure may change under future scenarios of climate change, subsidence, and socioeconomic development. Dasgupta et al. (2009) assessed the consequences of global sea-level rise for 84 coastal developing countries using a spatially disaggregated global database.

A prime example of a region requiring urgent information on flood damage exposure is Indonesia, since its $81,000-\mathrm{km}$ coastline and over 17,500 islands makes it particularly vulnerable to coastal flooding (Marfai and King 2008a). Marfai and King (2008a) developed a model to simulate the area covered by permanent coastal inundation (i.e. the area that would be permanently inundated as a result of sea-level rise and land subsidence) in the city of Semarang (Central Java, Indonesia) under two scenarios of sea-level rise and used this to estimate the damage exposure under those two scenarios (Marfai and King 2008b). However, the model was not applied for assessing the extent of temporary inundation as a result of extreme coastal flood events.

In the current paper, we are aiming at: (a) further developing a methodology for the rapid assessment of inundation mapping and damage exposure estimation under future scenarios of extreme coastal flood events; and (b) applying the method to the city of Jakarta to derive preliminary inundation maps and damage exposure estimates. The method is designed for ease of use by non-hydraulic experts, since its main aim is as a rapid decision support tool for decision-makers in Jakarta. Jakarta provides a relevant case study since the coastal defences in the north of the city already face extreme threats from coastal inundation (Deltares 2008).

\section{Study area}

Jakarta, the capital and largest city of Indonesia, is located in the northern coast of West Java (Fig. 1). The Special Capital Region of Jakarta (DKI Jakarta; Daerah Khusus Ibukota) covers an area of ca. $662 \mathrm{~km}^{2}$, and over the last half century, the city's population rose 


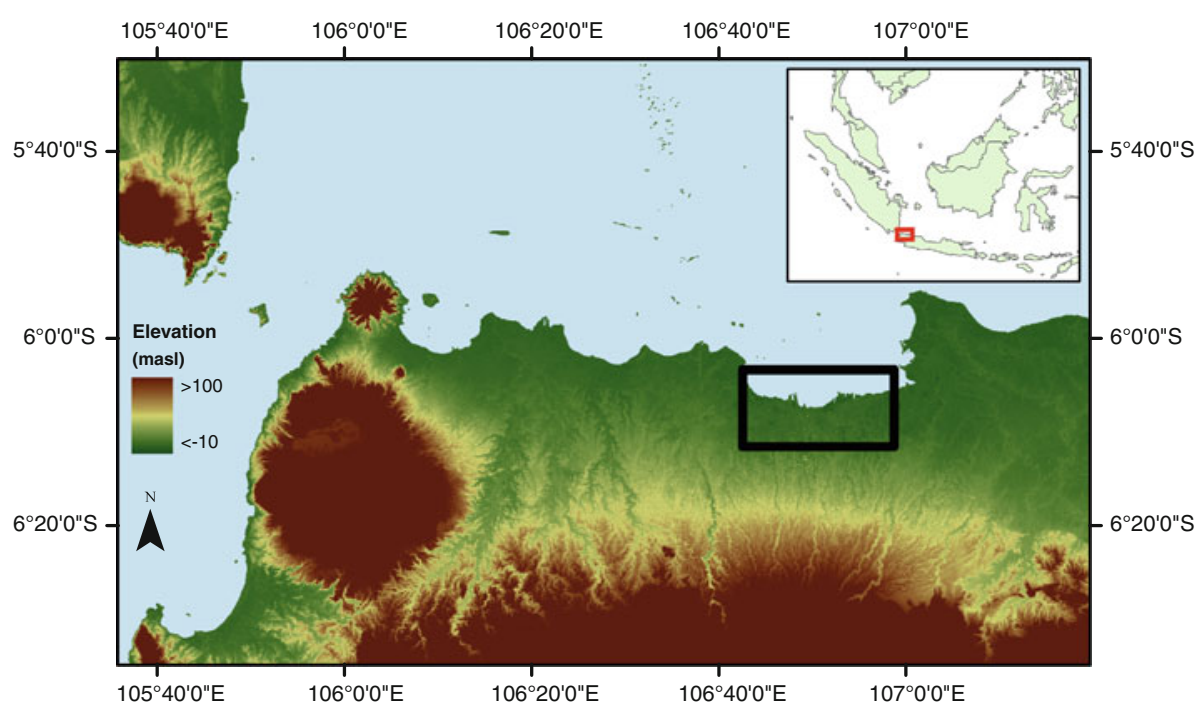

Fig. 1 Geographical location of the study area (shown by black box). The research focuses on northern Jakarta, in northwest Java, Indonesia. A detailed land use map of the study area can be found in Fig. 3

rapidly from 2.7 million in 1960 to 9 million in 2007 (BPS Jakarta 2007). These population pressures and economic developments have caused extensive land use change in the whole of Java (Verburg et al. 1999), and in Jakarta in particular (Firman 2009). During the past three decades, fringe areas have experienced extensive land conversion from prime agricultural land to new urban and industrial areas (Firman 2000; Verburg et al. 1999). Meanwhile, in the urban centre, many former residential areas have been converted into offices and business spaces, whilst open green space in Jakarta has greatly decreased from $28.8 \%$ of total area in 1984 to an estimated 6.2\% in 2007 (Firman 2009).

In terms of physical geography, Jakarta is a lowland area with a relatively flat topography, with slopes ranging from 0 to $2^{\circ}$ in the northern and central parts and $0-5^{\circ}$ in the southern part (Abidin et al. 2001). The area is subsiding, which already causes major problems such as the cracking of permanent constructions; the wider expansion of floodprone areas; and the lowering of groundwater levels (Abidin et al. 2001, 2010). Land subsidence has four possible causes, namely groundwater extraction, construction loads, natural consolidation of alluvium soil, and geotectonic adjustments (Harsolumakso 2001; Hutasoit 2001; Murdohardono and Sudarsono 1998; Rismianto and Mak 1993). The first three are believed to be the most dominant (Abidin et al. 2010). The results of three levelling surveys conducted between 1982 and 1997, eleven GPS surveys between 1997 and 2008, and InSAR technique between 2006 and 2007 show that land subsidence in Jakarta has large spatial and temporal variations. Observed subsidence rates are generally ca. 1-15 cm/year but can be up to $20-25 \mathrm{~cm} /$ year for certain locations and/or time periods (Abidin et al. 2001, 2004, 2008a, b). The spatial and temporal variations indicate that the sources of land subsidence may also differ spatially. There is a strong indication that land subsidence in the Jakarta area is related to the high volume of groundwater extraction from the middle and lower aquifers, with secondary contributions by building/construction loading and natural consolidation of sedimentary layers. In general, land subsidence in northern Jakarta is more rapid than in the south of the city. Recent estimates of Abidin 
et al. (2010) suggest an average subsidence rate of $4 \mathrm{~cm} /$ year in northern Jakarta, with more rapid subsidence shown in a number of cones of subsidence.

In this paper, the study area is confined to the northern Jakarta coastal area (Fig. 1), constituting parts of six districts, namely Penjaringan, Pademangan, Tanjuk Priok, Koja, Kelapa Gading, and Cilincing, which together cover an area of ca. 13,700 ha, with a population of ca. 1.2 million. This part of Jakarta is the most vulnerable to coastal inundation in terms of both sea-level rise and land subsidence. The area already has acute coastal inundation problems, and several temporary adaptation measures are already in place, such as the strengthening and heightening of thin sea walls, the construction of an elevated toll road to the international airport, and improvements to pumping stations and tidal gates (Deltares 2008).

\section{Methods}

The overall approach is based on that used by Nicholls et al. (2008) but uses more localised data sets. We use a GIS-based inundation model to produce inundation maps for given coastal flood events under both current environmental conditions and scenarios of future environmental change. The input required by the inundation model is a digital elevation model (DEM) and the difference in sea level between a given flood scenario and current mean sea level (hereinafter referred to as 'flood water level' and given in metres above current mean sea level (masl)). The output inundation map is overlaid with a map of land use, and each land use assigned an economic value, in order to calculate the maximum damage exposure. The overall modelling chain is shown in Fig. 2. In the following paragraphs, we first describe the inundation model, followed by its required data, and finally the methods and data used to convert these to damage exposure estimates.

\subsection{Inundation model}

Marfai and King (2008b) developed a flood inundation model for Semarang (Java, Indonesia) using a GIS-based approach and a detailed DEM. They subsequently applied this model to two scenarios of sea-level rise and land subsidence to assess the extent of land that would be exposed to these permanent inundations, as well as the maximum direct economic value of the exposed assets (Marfai and King 2008a). In this study, we use this

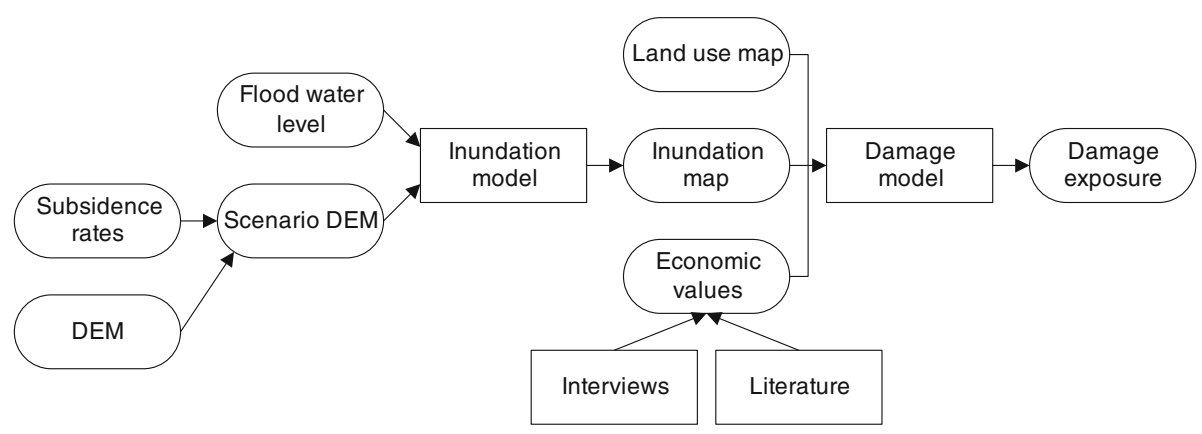

Fig. 2 Flow chart showing the general research approach and methodology 
model to assess flood extent and economic exposure to extreme coastal flood events in Jakarta.

The structure of the inundation model is described thoroughly in Marfai and King (2008b); here, we provide a summary of the main points. The inundation model operates in the ILWIS GIS environment and produces a map showing which grid cells would be inundated for a given flood water level (inundation map). In the past, the model was used to simulate permanent inundation due to relative sea-level rise, but we here apply it to temporary coastal flood events (for example, temporary inundation caused by a storm surge with a recurrence period of 100 years). A neighbourhood operation is applied in ILWIS to calculate the spreading of flood waters from the coast onto the adjacent land area. Firstly, the flood water level is given as an input parameter. Along the coastal segment being studied, the neighbourhood operation assesses those grid cells along the coastal strip whose elevation is lower than the given flood water level scenario; in the model, these cells are inundated up to the difference in depth between the grid-cell elevation and the flood water level. This process is then repeated iteratively using a pixel-by-pixel analysis on a $3 \times 3$ cell window around the inundated cells until the full potential inundation area is reached. Hence, the inundated area has a logical extent whereby all flooded cells are connected to each other along a (flow) path, rather than simply assuming that all cells lower than the extreme sea-level height will be inundated (Marfai and King 2008b). In this study, the model is run at a spatial resolution of $5 \mathrm{~m} \times 5 \mathrm{~m}$.

The use of GIS for coastal flood simulation is not new (see, for example Shennan (1993), and references therein). There are many other methods available to simulate costal inundation (depths) (e.g. Bates et al. 2005; Bryan et al. 2001; Dawson et al. 2005; Madsen and Jakobsen 2004; Mastin and Olsen 2002; Nicholls 2002, 2004; Nicholls et al. 2008; Purvis et al. 2008; Thumerer et al. 2000), but in essence, all of these attempt to predict inundation extents and depths based on some combination of process drivers (such as meteorology, tides, and flood defence design periods) (Dawson et al. 2005). There are two main approaches: planar models and hydrodynamic models. Planar models, such as the one used in this study, use as input the water level of the tide and distribute this over a DEM by means of some kind of flow-connectivity algorithm. For the planning and implementation of protection measures, predictions are typically obtained from hydrodynamic models; for coastal flows, two-dimensional horizontal solutions of the shallow water equations are state of the art (Madsen and Jakobsen 2004; Bates et al. 2005). Such models require accurate topographic and bathymetric data at a high resolution and are computationally demanding. Hence, Bates et al. (2005) developed a simplified two-dimensional hydraulic model with much less computational demand, following similar advances in fluvial inundation modelling (Horritt and Bates 2002). Nevertheless, such models still require a rather large degree of hydraulic expertise, and hence, we consider the more simplified GIS-based planar approach to be appropriate for the kind of rapid assessment and decision support tool to be developed here. Moreover, this method has been tested and validated for the city of Semarang (coastal Java) by Marfai et al. (2008a, b, c).

\subsection{Inundation model input data}

\subsubsection{Digital elevation model}

The main input required for the simulation of the inundation extent and depths is a digital elevation model (DEM). The DEM for the current conditions was interpolated using the ILWIS GIS package, based on topographic maps of BAKOSURTANAL (Indonesian 
Survey and Mapping Coordination Agency) (scale 1:25,000). The original topographic maps show point elevation data in 1998; the point data are distributed irregularly throughout the area, with more points in those areas with relatively greater elevation variability. This point map was interpolated to $5 \mathrm{~m} \times 5 \mathrm{~m}$ using ILWIS GIS software. Given the rapid subsidence in the area, these data are out of date. However, they represent one of the better and most used data sets for planning in Jakarta and are hence used here. To correct for land subsidence since 1998, the DEM was adjusted in GIS according to the subsidence rates over the last decade reported in Abidin et al. (2001, 2008a, b). Ideally, the model would make use of up-to-date high-resolution data such as LiDAR or digital air photographs with extensive ground-truthing; however, these were not available. Hence, we carried out ground-truthing for several control points.

For the future scenarios, we developed different DEMs for each scenario of land subsidence. We used the subsidence rates discussed in Abidin et al. (2010), as presented in Sect. 2 (i.e. $4 \mathrm{~cm} / \mathrm{yr}$ on average) to project land subsidence to 2100 and hence generated a future scenario DEM, using the algorithm of Marfai and King (2007):

$$
\operatorname{DEM}_{t(x)}=\operatorname{DEM}_{t(0)}-\left(s *\left(t_{x}-t_{0}\right)\right)
$$

where $\operatorname{DEM}_{t(x)}$ is the DEM at time ( $t$ ) (i.e. year) $x, \mathrm{DEM}_{t(0)}$ is the DEM in the baseline year $\left(t_{0}\right)$, and $s$ is the spatially differentiated annual rate of subsidence in centimetres. The use of this method allows for a simple reassessment of the future DEM as updated and improved estimates of (spatial and temporal) subsidence rates become available.

\subsubsection{Flood water level scenarios}

In the inundation model, the flood water level (masl) is given as input and is used to assess which land cells would be inundated if such a flood event occurs. Estimates of flood water level associated with a return period of 100 years $(1: 100)$ and 1,000 years $(1: 1,000)$ under current conditions were derived from the DIVA (Dynamic Interactive Vulnerability Assessment) model (Dinas-Coast Consortium 2006). For the 1:100 event, the associated flood water level is estimated at ca. 1.596 masl, and for 1:1,000, at 1.880 masl. Following the method of Nicholls et al. (2008), we assume that future sea-level rise will cause the flood water level associated with these events to change by the magnitude of the sea-level rise. For example, a rise in mean sea level of $0.5 \mathrm{~m}$ would result in an increase of the 1:100 flood water level to 2.096 masl. Furthermore, since recent research suggests that storm activity will increase in the Indonesian region in the future (APN 2008), but large uncertainty remains as regards the magnitude of that change, we use the storm enhancement factor of 1.1 (Nicholls et al. 2008) to simulate the impacts of increased storm intensity on flood water levels in the Jakarta Bay by 2100. The storm enhancement factor is a factor by which the 1:100 and 1:1,000 flood water levels are multiplied in order to account for increased storm intensity.

Detailed projections of the impacts of climate change on sea-level rise in the Jakarta Bay in the 21st century are not available. However, the observed change of ca. $0.5 \mathrm{~cm}$ per year in recent decades reported by Pribadi (2008) falls within the range of global sealevel rise reported by the IPCC (2007b). Hence, we used two scenarios of sea-level rise by 2100 to give a range of possible futures, using the maximum and minimum likely global average mean sea-level rise estimates for the six families of IPCC scenarios, i.e. 18 and $59 \mathrm{~cm}$ (IPCC, 2007b); we refer to these scenarios as low and high sea-level rise, respectively. 


\subsection{Damage exposure estimation}

Using the DEMs and the flood water levels for the current and future scenarios, the inundation model is used to map the associated inundation extent on an inundation map. Each grid cell in the study area is also assigned a land use, and each land use is assigned an economic value (per hectare). This value represents the estimated market value of the buildings and material assets per hectare for each land use class. By overlaying the inundation maps on the land use maps, we estimated the total inundated area in each land use class and also the total value of exposed assets (damage exposure) per land use class. It should be noted that this represents the maximum potential damage exposure, since the actual damage that would occur as a result of each inundation scenario is also dependent on other factors, such as water depth in the inundated area (e.g. Merz et al. 2007), flow velocity (e.g. Kreibich et al. 2009), flood mitigation measures (e.g. Nicholls et al. 2008), and sediment load (e.g. Ward et al. 2009).

The land use map of the study area is based on an updated version of detailed topographic maps of the Jakarta local government (Pemerintah Kota Jakarta, Dinas Pertanahan dan Pemetaan) for the year 2004 (based on aerial photography in the year 2003). These maps were updated by means of visual image analysis based on an IKONOS image of the year 2007. The resulting map has a horizontal resolution of $5 \mathrm{~m} \times 5 \mathrm{~m}$ and was reclassed to show seven major land use classes, as shown in Fig. 3.

Average market values of buildings and tangible assets (per hectare) were estimated for each of the land use classes. Market valuations were assigned based on interviews carried out for this study (for the land use categories uniform and non-uniform settlements) and on existing literature and statistics for the other land use types. In this study, settlements are split into two categories, namely uniform settlements and non-uniform settlements. Uniform settlements refer to households with a medium to high income, and non-uniform settlements refer to households with low income; the value of assets per hectare was found to differ between the two categories. The value of assets for uniform settlements was

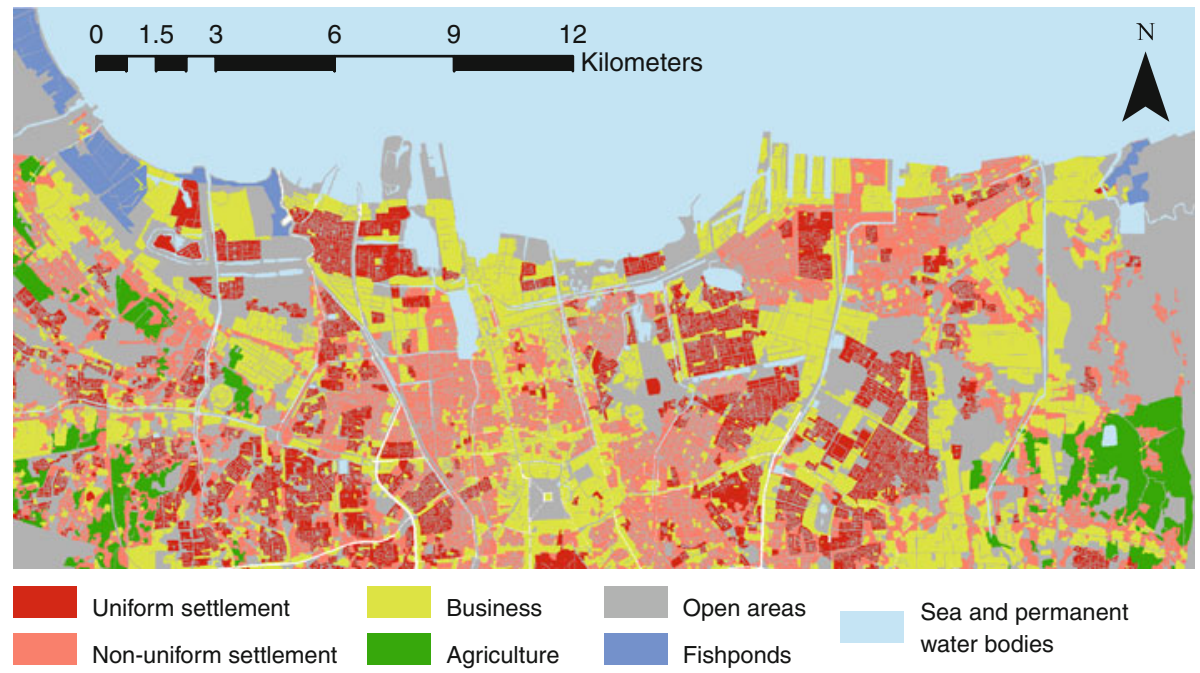

Fig. 3 Land use map of the study area based on IKONOS satellite imagery and ground-truthing, reclassed to seven major land use classes. The land use map has a spatial resolution of $5 \mathrm{~m} \times 5 \mathrm{~m}$. Source: Transavia Consultancy 
estimated to be ca. $€ 1.2$ million per hectare, and that of non-uniform settlements to be ca. $€ 1$ million per hectare. National and regional statistical data from Indonesia provide an estimate of the value of assets in agricultural areas in Semarang (coastal Java) at ca. $€ 80,000$ per hectare (DPB 2002; DGEM 2004; Marfai and King 2008a); we have assumed the same valuation for agricultural areas in Jakarta. National statistical data and survey reports were also used to estimate the following mean values of assets per hectare: business areas (€2.5 million); fish ponds (€95,000); and open areas (€1,700) (DGEM 2004; Marfai and King 2008a). These valuations present only a first-order approximation of the true market value per hectare of each land use class, and in reality, the market values associated with the different land use types are highly heterogeneous. Hence, the absolute values of our damage exposure estimates should be interpreted with care, and the assessments made here should be considered as indicative. However, the estimates do provide a good impression of the relative change in damage exposure due to environmental changes.

\section{Results and discussion}

In this section, we present and discuss the results for two sets of analyses. In Sects. 4.1 and 4.2 , we present results pertaining to a scenario analysis, whereby inundation maps and damage exposure estimates were calculated for a number of discrete future scenarios. In Sect. 4.3, we explore a methodology for the rapid assessment of damage exposures under future uncertainty.

\subsection{Scenario results of flood inundation and damage exposure estimates}

The simulations were carried out for six inundation scenarios pertaining to both current conditions (i.e. conditions in 2009) and theoretical future conditions in 2100. The scenarios are described in Table 1.

Under current conditions, the area that would be inundated by a coastal flood with a return period of 100 years is ca. 3,400 ha, with a corresponding damage exposure of ca. $€ 4.0$ billion (Fig. 4a and b, respectively). Both the inundated area and damage exposure increase by a factor of ca. 1.3 under current conditions for a coastal flood with return period of 1,000 years. For both of these scenarios, the total inundated area is made up of approximately one-third business area and one-third residential (combined uniform and non-uniform settlement) (Fig. 4c); although given the larger market value associated with business areas, $72 \%$ of the total damage exposure is in those areas (Fig. 4d). Maps showing

Table 1 Description of the scenarios used to run the inundation model

\begin{tabular}{|c|c|c|c|c|}
\hline Scenario name & $\begin{array}{l}\text { Recurrence } \\
\text { period }\end{array}$ & Sea-level depth & $\begin{array}{l}\text { Storm } \\
\text { enhancement } \\
\text { factor }\end{array}$ & DEM \\
\hline $\mathrm{SL}_{2009}: 1: 100$ & $1: 100$ & Current & 1.0 & Current \\
\hline $\mathrm{SL}_{2009}: 1: 100$ & $1: 1,000$ & Current & 1.0 & Current \\
\hline SL $_{2100 l o w}: 1: 100$ & $1: 100$ & $+18 \mathrm{~cm}$ (IPCC low) & 1.1 & Land subsidence 2100 \\
\hline $\mathrm{SL}_{210010 w}: 1: 1,000$ & $1: 1,000$ & $+18 \mathrm{~cm}$ (IPCC low) & 1.1 & Land subsidence 2100 \\
\hline $\mathrm{SL}_{2100 \text { high }}: 1: 100$ & $1: 100$ & $+59 \mathrm{~cm}$ (IPCC high) & 1.1 & Land subsidence 2100 \\
\hline SL $_{2100 h i g h}: 1: 1,000$ & $1: 1,000$ & $+59 \mathrm{~cm}$ (IPCC high) & 1.1 & Land subsidence 2100 \\
\hline
\end{tabular}




\section{a}

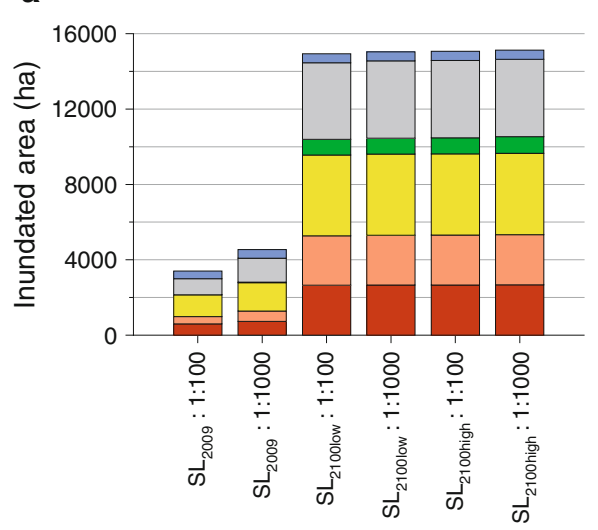

C

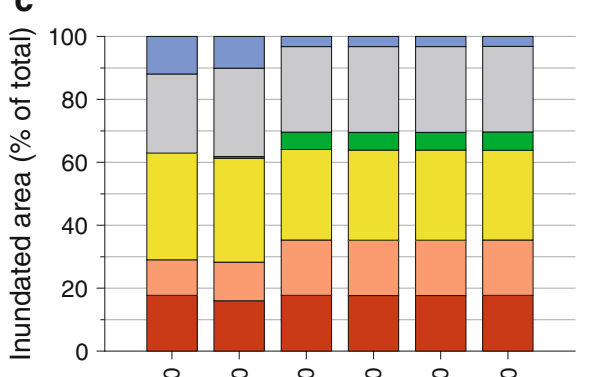

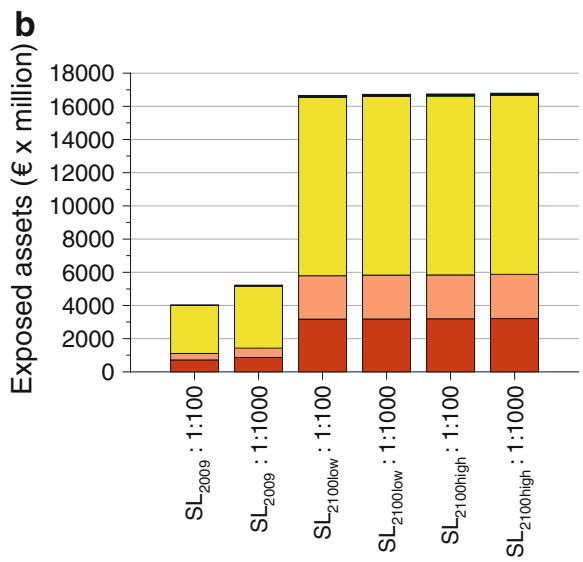

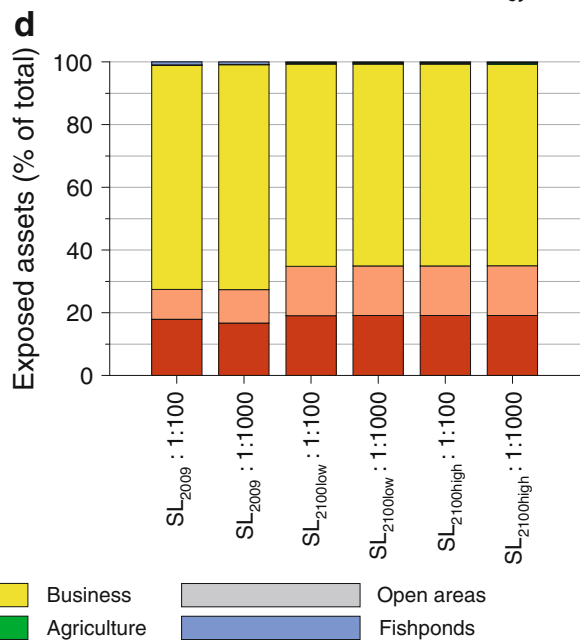

Fig. 4 Simulation results for the six inundation scenarios showing: a inundated area per land use (ha); b exposed assets per land use (million Euros); c inundated area per land use as a percentage of total inundated area; and $\mathbf{d}$ exposed assets per land use as a percentage of total exposed assets

the spatial extent of inundation under these scenarios can be found in Fig. 5. These maps show that, logically, the coastal areas of northern Jakarta are the most susceptible to coastal flooding, although a large area of uniform settlement extending southwards from the middle of the area would also be exposed to these flood events under current conditions.

For the scenarios in 2100, the inundation maps (Fig. 5) show a huge increase in the inundated area for both the low and high flood water level scenarios, and for flood events with a return period of 100 and 1,000 years, when compared to those under current conditions. In contrast, the maps show minimal difference in the flood extent between the four scenarios for 2100. This is reflected in the results shown in Fig. 4, where total inundated area in the scenarios for 2100 ranges between 14,900 and 15,100 ha and the corresponding damage exposure ranges between $€ 16.7$ and $€ 16.8$ billion. The relative share of residential area in the total inundated area increases between the scenarios under current and future conditions from ca. 28 to ca. $36 \%$, with a disproportionate increase in inundation in non-uniform settlement relative to uniform settlement. 
(a) $\mathrm{SL}_{2009}: 1: 100$

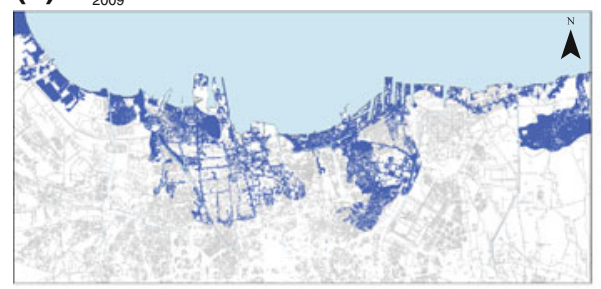

(c) $S_{210010 w}: 1: 100$

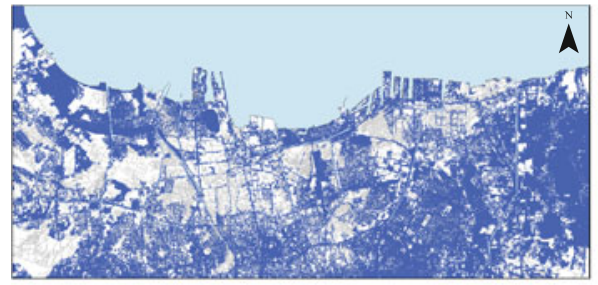

(e) $S_{2100 \text { high }}: 1: 100$

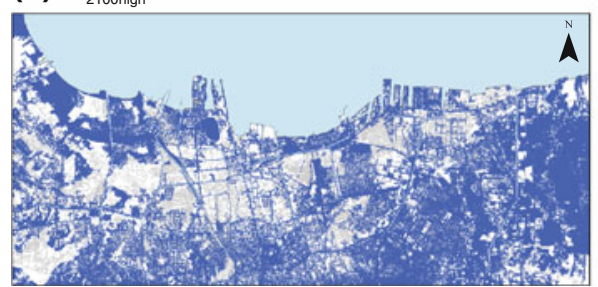

(b) $\mathrm{SL}_{2009}: 1: 1000$

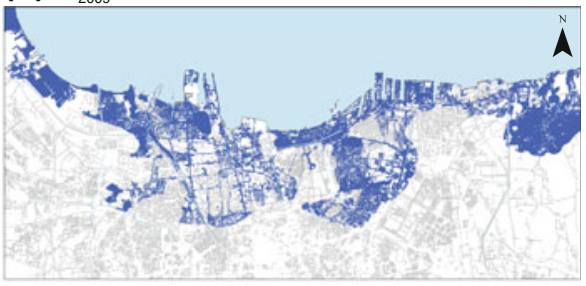

(d) $\mathrm{SL}_{210010 \mathrm{w}}: 1: 1000$

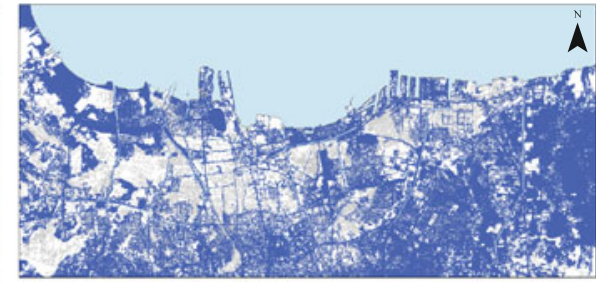

(f) $\mathrm{SL}_{2100 \text { high }}: 1: 1000$

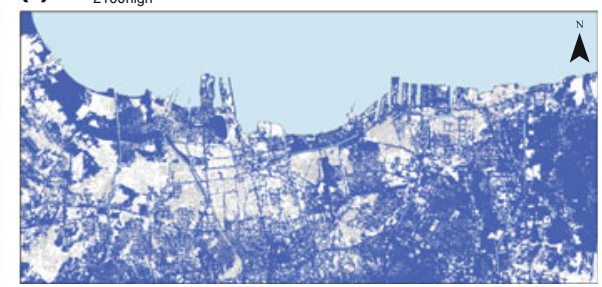

$\square$ Sea and permanent water bodies
Inundated area

Fig. 5 Inundation maps for the six discrete scenarios of extreme coastal flooding. The area shown on the map is $29.8 \mathrm{~km} \times 14.1 \mathrm{~km}$

Across all of the scenarios, the inundated area (and hence damage exposure) of fish ponds remains fairly constant, since this land use is located at low elevations along the coast and is therefore the first to be affected by relatively shallow coastal flood events.

\subsection{Implications of the scenario results}

Under current conditions, the value of assets exposed to extreme coastal inundation is already high. According to the World Development Indicators (WDI) database of the World Bank, the gross domestic product (GDP) of Indonesia in 2008 was ca. $€ 351$ billion (in 2008 values). Hence, the estimated maximum value of exposed assets in Jakarta alone to a 1:100 year costal flood event represents ca. $1.2 \%$ of the country's national GDP, whilst the estimated maximum value of exposed assets to a 1:1,000 year event represents $1.5 \%$ of total national GDP. It should be noted that damage exposure does not necessarily translate into impact, since the linkage between exposure and residual risks of impact depends upon flood protection measures (Nicholls et al. 2008). Nevertheless, since Jakarta's coastal protection measures are already prone to failure in the event of high tides (Deltares 2008), they would offer minimal protection in the case of these extreme events. Hence, these 
results show that even without environmental and/or socioeconomic changes, the need for improved coastal protection measures is already critical.

The scenarios carried out for the year 2100 were intended to provide an assessment of the relative influences of long-term changes in environmental factors (in this case, namely sea-level rise, subsidence, and storm intensity) on inundation and damage exposure in Jakarta. However, we see in all of the scenarios for 2100 that the flood inundation area and, as a result, the damage exposure, is extremely high, with little difference between the scenarios. This shows that on this time scale, the impacts of changes in climate on extreme coastal flood events may be very small when compared to the impacts of land subsidence. The differences in impact (on inundation area and damage exposure) between the low sealevel rise scenarios and the high sea-level rise scenarios are minimal, since it appears that a critical level has already been reached as a result of the projected land subsidence.

The use of this scenario approach highlights several problems. Firstly, whilst, in these scenarios, it appears that the effects of climate change-related changes in sea level may have a relatively minor impact on coastal flood exposure in northern Jakarta, this may not be true for lower levels of subsidence. In fact, the reason that the additional impacts of sealevel rise (on top of land subsidence) on damage exposure are so small is because the severe land subsidence scenario used here already leads to the near total flooding of Jakarta under extreme coastal flood events by 2100 , so that the additional impacts of sea-level rise are not seen. The land subsidence scenario used in this study is itself highly uncertain, since it is unlikely that subsidence will continue in a linear fashion as assumed here. Moreover, if measures are taken to strictly regulate groundwater extraction, the subsidence scenario could prove to be too high, in which case the relative impact of other environmental changes would increase. Secondly, this scenario approach does not give information to the decisionmaker that is of use within the decision-making time frame. Many (infrastructural) adaptation plans use a much shorter time frame (e.g. 20-40 years, World Bank 2010), so that the projections to 2100 remain abstract. Thirdly, and related to the second point, all of the projections used here are subject to large uncertainties, particularly in the timing of when they will occur. For example, even if we were to assume that sea level will eventually rise by $59 \mathrm{~cm}$, it is unclear at what point this will be reached. Since the same is true for land subsidence, it is impossible to 'predict' dates at which critical flood water levels will be reached. For adaptation planning, it may therefore be useful to provide simple scenarios of inundation extent and/or damage exposure based on hypothetical future trajectories where the time element has been removed or detemporalised. In the following section, we provide a rapid assessment framework of detemporalised inundation results for northern Jakarta.

\subsection{Detemporalised inundation scenarios}

Given the uncertainties as regards both the magnitude and timing of changes in sea level, land subsidence, and storm intensity, we present a hypothetical detemporalised scenario that could be used to assess adaptation options in terms of their effectiveness against given magnitudes of environmental change, rather than their effectiveness at specific dates. To do this, we ran more simulations with the inundation model based on flood water level scenarios from 0.0 to 6.0 masl, with intervals of $0.5 \mathrm{~m}$. These scenarios refer to the flood water level (relative to mean current sea level) as a combination of all driving factors. For example, the scenario of 1.5 masl refers to a flood water level of $1.5 \mathrm{~m}$ above mean current sea level, but is not bound to a given recurrence interval, and can be a result of either actual changes in sea level or changes in the relative sea level due to land subsidence, or a combination of both. The resulting inundation maps for these scenarios are shown in 

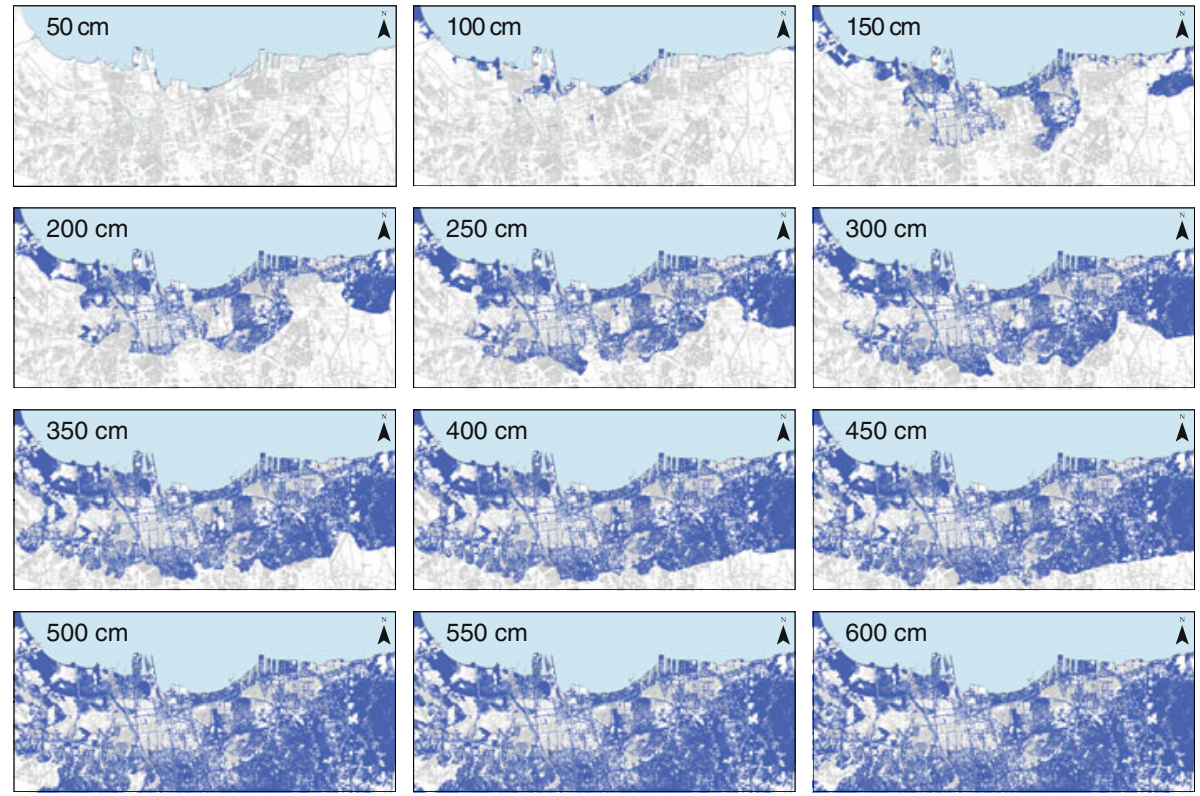

Sea and permanent water bodies

Inundated area

Fig. 6 Inundation maps for flood water levels between 0.5 and 6.0 masl (above mean current sea level). The area shown on the map is $29.8 \mathrm{~km} \times 14.1 \mathrm{~km}$

Fig. 6. The graph in Fig. 7 shows the associated damage exposure associated with these inundation maps and can be used to derive an approximate estimate of the total value of exposed assets, as well as the value of exposed assets in each land use class, for any flood water level scenario between 0.0 and 6.0 masl.

The results show that both the inundation extent and the damage exposure remain low to a flood water level of 1.0 masl. However, for flood water levels between 1.0 and 1.5 masl, we see a very rapid increase in damage exposure for business areas, which is the key component responsible for the increase in exposure from $€ 0.7$ to $€ 3.7$ billion. Under current conditions, coastal floods related to a flood water level of 1.5 masl are expected to occur slightly more frequently than once per 100 years, and since the subsidence rate is currently continuing at an average of $4 \mathrm{~cm} / \mathrm{yr}$, this return period shortens each year. Whilst the method presented here is primarily designed to provide rapid damage assessments for temporary inundation events associated with extreme flood water levels, it can also be used to gain insights into the damage exposure to permanent flooding related to sea-level rise relative to present. In this case, the so-called flood water level refers to the mean sea-level rise compared to present, rather than the water level associated with an extreme event.

Damage exposure then shows a fairly constant increase up to a flood water level of ca. 3.5 masl, with an increase in exposure of ca. $€ 30.6$ million per centimetre (due to increases in the area of inundated business and residential areas). Between 3.5 and 4.5 masl, the rate of increase in exposure is less rapid, but we see a second critical point occurring at a flood water level of 4.5 masl. If land subsidence in Jakarta continues in the coming century at the same rate as observed in the last decade, coastal flood events of this magnitude would be 
Fig. 7 Curves showing the total value of exposed assets and the value of exposed assets per land use class, for flood water levels between 0.0 and 6.0 masl (above mean current sea level). Note that the land use classes 'open areas' and 'fish ponds' are not shown, since these values were negligible

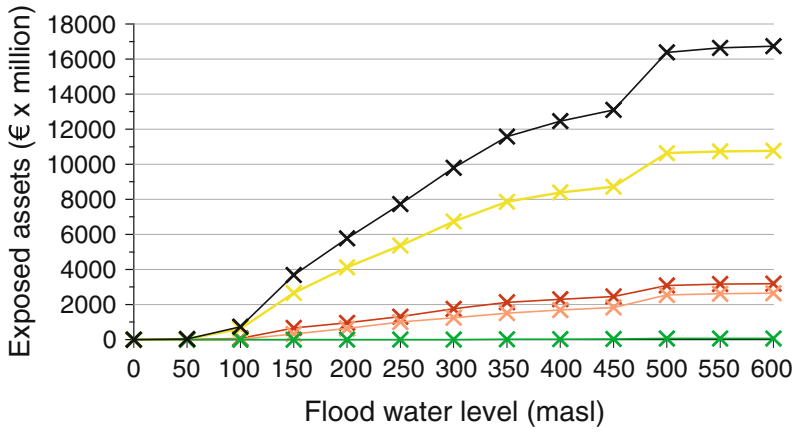

Uniform settlement

Non-uniform settlement

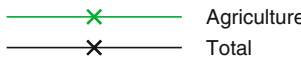

Business

expected much more frequently than once per 100 years by the end of the 21 st Century, even without sea-level rise.

In terms of coastal flood adaptation development, such a rapid assessment technique is useful since it allows planners to assess the effectiveness of measures against concrete estimates of the impacts of inundation. Moreover, the method allows us to assess the impacts of combined environmental changes in the face of uncertainty, since the estimates pertain to flood scenarios independent of both time and the individual contributions of different environmental changes. Thereby, the results shown in Fig. 7 facilitate an identification of critical points above which large increases in damage exposure can be expected. Finally, the scenario assessment allows us to examine the impacts of changes in different factors relative to each other in the case of northern Jakarta thus showing the need for both further research and adaptation in the field of land subsidence. Nevertheless, given the fact that damage exposure is already substantial for the current 1:100 year coastal flooding event, the effects of sea-level rise due to climate change should also constitute a major part of any integrated coastal protection plan.

\subsection{Limitations and future work}

The research presented in this paper examines the total value of exposed assets to flood inundation. We stress again that this is not the same as the actual damage that would occur as a result of each inundation scenario, since this is also be dependent on other factors, such as water depth in the inundated area, flow velocity, flood mitigation measures, and sediment load. Several studies identified the inundation depth as the flood characteristic with the largest influence on flood damage (e.g., Penning-Rowsell et al. 1994; Wind et al. 1999). In future research, we intend to develop stage damage functions (SDFs) to examine the damage that would occur with given inundation depths (as per Bouwer et al. 2009), since inundation depths are provided as output of our model. SDFs are based on a maximum damage value per land use type, as is the case here, but they also estimate the proportion of the maximum damage that would actually be incurred for a given inundation depth (Merz et al. 2007). To date, no such relationships have been derived for Indonesia. The selection of SDF has a huge impact on the estimated damage. For example, De Moel and Aerts (2009) showed that for a dike-ring area in the Netherlands, the estimated damage varies by up to a factor of four when using three different SDFs, namely those of ICBR (2001); Vanneuville et al. (2006), and Klijn et al. (2007); this is especially the case in urban areas. 
Hence, it is important to use SDFs tailored to the local situation, rather than simply adopting SDFs from other regions. In following research, we will estimate the function of these curves based on a combination of empirical data relating observed flood damage to observed historical events (as is the case for the HOWAS database, see Merz et al. 2004) and via expert judgement (see, for example, Penning-Rowsell et al. 2003).

The absolute values of the damage exposure estimates should be interpreted with care, since in reality, the market values associated with the different land use types are highly heterogeneous and the assessments made here should be considered as indicative. However, the estimates do provide a good impression of the relative change in damage exposure due to environmental changes.

Environmental changes are by no means the only factors responsible for changes in future damage exposure. Internationally, socioeconomic developments in the future will lead to increases in the economic value of developments in flood-prone areas, and population density will increase leading to larger exposed populations (Bouwer et al. 2007). Recent research suggests that socioeconomic changes (including population, economic growth, and land use) may have a similar or greater impact on economic damage and populations at risk than do changes in environmental factors (e.g. World Bank 2010); this may be particularly the case in rapidly developing areas such as Jakarta. Hence, in the following steps, scenarios of socioeconomic change will be developed with key stakeholders in order to assess the impacts of those changes relative to the impacts of environmental factors.

Flood risk management requires accurate and up-to-date data on elevation of land at risk. The DEM used here was generated from a rather old topographic map, and as such, extra uncertainties are introduced. The acquisition of LiDAR data and a regular field campaign of digital air photography and ground-truthing would be beneficial to city planners in this regard. Due to other data constraints, the current research has focused on northern Jakarta, since this is the part of the city with the highest vulnerability to coastal flooding and with the most critical problems. However, the results presented here show that flood water levels above ca. 4.5 masl will also affect large parts of the city to the south of this area. Hence, future research will also include the entire region of DKI Jakarta. Given further efforts in data collection, the tool could also be implemented more generically to assess flood exposures in coastal Indonesia more widely.

\section{Conclusions}

We have developed a GIS-based decision support tool originally designed for mapping permanent coastal inundation, for use in inundation mapping and damage exposure estimation for extreme coastal flood events in cities, and applied the tool to the case study of Jakarta. Multilateral agreements between Indonesian and foreign government agencies are already in place to take swift action to prepare decisions on how the future coastal defence of Jakarta should be improved; rapid tools for the spatial assessment of the sensitivity of flood hazard and damage exposure can play a key role in such processes.

We estimated the potential flood extent and damage exposure to a 1:100 year and 1:1,000 year extreme coastal flood event under current conditions and scenarios for 2100 assuming land subsidence, increased storm intensity, and low and high sea-level rise scenarios. Under current conditions, the damage exposure estimates to these extreme flood events are already high, at ca. €4.0 billion (for 1:100 year events) and $€ 5.2$ billion (for 1:1,000 year events), corresponding to ca. 1.2 and 1.5\%, respectively, of Indonesia's GDP 
in 2008. Under the scenarios for 2100, the damage exposure estimate increases to almost $€ 17$ billion, with hardly any difference between the 1:100 and 1:1,000 year events or the low or high sea-level rise scenarios. This is because the scenario of land subsidence is so severe that most of the vulnerable areas in northern Jakarta are already flooded at this depth. The use of this scenario approach reveals a number of clear drawbacks: (a) we use only a very limited number of scenarios for the period to 2100 , including one scenario of land subsidence. However, there is great uncertainty in these scenarios, especially regarding the timing of environmental changes; (b) using a time horizon to 2100, land subsidence is so dominant that the possible impacts of other environmental factors are masked, even though they may be important for lower subsidence rates; and (c) the scenarios of 2100 do not provide information to decision-makers that are of use within the decision-making time frame.

Hence, we developed a method for the rapid assessment of damage exposure under these uncertainties, by detemporalising the future scenarios. Instead of providing estimates for a given date in time, we show simple curves where inundation exposure is related to a given flood water level compared to mean current sea level. This is not bound to a given date, nor to a specific causal mechanism, but can result as a combination of any of the environmental factors studied. The method allows for the identification of critical points above which large increases in damage exposure can be expected and also allows for the assessment of adaptation options against hypothetical user-defined levels of change, rather than being bound to a discrete set of a priori scenarios.

The study highlights the need for urgent attention to the land subsidence problem, since a continuation of the current rate into the future would result in a catastrophic increase in damage exposure. We are careful to highlight that much more research is still required, especially to assess the impacts of future changes in socioeconomic parameters (especially land use, economic value, and population) on damage exposure.

Acknowledgments We would like to thank the Jakarta local government (Pemerintah Kota Jakarta, Dinas Pertanahan dan Pemetaan) and Transavia Consultants for the provision of data sets. We also thank two anonymous reviewers for their valuable comments on an earlier version of the manuscript. The research was supported by the Dutch research programme Knowledge for Climate, the Connecting Delta Cities network, and a grant from the KNAW (Royal Netherlands Academy of Arts and Sciences) Mobility Programme (09-MP-10).

Open Access This article is distributed under the terms of the Creative Commons Attribution Noncommercial License which permits any noncommercial use, distribution, and reproduction in any medium, provided the original author(s) and source are credited.

\section{References}

Abidin HZ, Djaja R, Darmawan D, Hadi S, Akbar A, Rajiyowiryono H, Sudibyo Y, Meilano I, Kusuma MA, Kahar J, Subarya C (2001) Land subsidence of Jakarta (Indonesia) and its geodetic monitoring system. Nat Hazards 23:365-387. doi:10.1023/A:1011144602064

Abidin HZ, Djaja R, Andreas H, Gamal M, Hirose IK, Maruyama Y (2004) Capabilities and constraints of geodetic techniques for monitoring land subsidence in the urban areas of Indonesia. Geo Res Aust $81: 45-58$

Abidin HZ, Andreas H, Djaja R, Darmawa D, Gamal M (2008a) Land subsidence characteristics of Jakarta between 1997 and 2005, as estimated using GPS surveys. GPS Solutions 12:23-32

Abidin HZ, Andreas H, Gamal M, Susanti P, Hutasoit L, Fukuda Y, Deguchi T, Maruyama Y (2008b) Land subsidence characteristics of the Jakarta Basin (Indonesia) as estimated from leveling, GPS and InSAR and its relation with groundwater extraction. Proceedings of 36th IAH congress, 26 October-1 November 2008, Toyama, Japan 
Abidin HZ, Andreas H, Gumilar I, Gamal M, Susanti P, Fukuda Y, Deguchi T (2010) Land subsidence in Jakarta basin (Indonesia): characteristics, causes and impacts. IAHS book series groundwater system response to a changing climate. CRC Press/Balkema on Groundwater and Climate Change, in press

Aerts JCJH, Major DC, Bowman MJ, Dircke P, Marfai MA, Abidin HZ, Ward PJ, Botzen W, Bannink BA, Nickson A, Reeder T (2009) Connecting delta cities. Coastal adaptation, flood risk management and adaptation to climate change. VU University Press, Amsterdam

APN (2008) Integrating Indonesian capacity for coastal zone management. Labmath-Indonesia, Bandung

Bates PD, Dawson RJ, Hall JW, Horritt MS, Nicholls RJ, Wicks J, Hassan MAAM (2005) Simplified twodimensional numerical modeling of coastal flooding and example applications. Coast Eng 52(9):793-810

Bouwer LM, Crompton RP, Faust E, Höppe P, Pielke RA Jr (2007) Confronting disaster losses. Science 318:753

Bouwer LM, Bubeck P, Wagtendonk AJ, Aerts JCJH (2009) Inundation scenarios for flood damage evaluation in polder areas. Natural hazards and earth system sciences 9:1995-2007. www.nat-hazardsearth-syst-sci.net/9/1995/2009/

BPS Jakarta (2007) Jakarta dalam angka 2007. Katalog BPS: 1403.31. Badan pusat statistik propinsi DKI Jakarta, Jakarta, Indonesia

Bryan B, Harvey N, Belerio T, Bourman B (2001) Distributed process modeling for regional assessment of coastal vulnerability to sea level rise. Environ Model Assess 6:57-65

Chatterjee RS, Fruneau B, Rudant JP, Roy PS, Frison P-L, Lakhera RC, Dadhwal VK, Saha R (2006) Subsidence of Kolkata (Calcutta) City, India during the 1990s as observed from space by differential synthetic aperture radar interferometer (D-InSAR) technique. Remote Sens Environ 102:176-185

Dasgupta S, Laplante B, Meisner C, Wheeler D, Yan J (2009) The impact of sea level rise on developing countries: a comparative analysis. Climatic Change 93:379-388. doi:10.1007/s10584-008-9499-5

Dawson R, Sayers P, Hall J, Hassan M, Bates P (2005) Efficient broad scale coastal flood risk assessment. In: McKee Smith, J (eds) Coastal engineering 2004: proceedings of the 29th international conference, Lisbon, Portugal 1924th September 2004. World Scientific, New Jersey, 3061-3073

De Moel H, Aerts JCJH (2009) Uncertainty and sensitivity assessment of flood risk assessments. Eos transactions AGU. Fall meeting supplement 90(52): NH52A-05

Deltares (2008) Flood hazard mapping 2-Overview. Report number Q0743.00. Deltares, Delft, The Netherlands

DGEM (2004) Civil-society and inter-municipal cooperation for better urban services/mitigation of geohazards. Directorate of geological and mining area environment (DGME). Department of Energy and Mineral Resources, Jakarta, Indonesia

Dinas-Coast Consortium (2006) Dynamic interactive vulnerability assessment (DIVA). Potsdam institute for climate impact research, Potsdam, Germany. http://diva.demis.nl. Accessed 31 March 2009

DPB (2002) Semarang city planning 2000-2010 (In Indonesian). Development Planning Board of Semarang (DPB), Semarang

Ericson JP, Vörösmarty CJ, Dingman SL, Ward LG, Meybeck M (2006) Effective sea-level rise and deltas: causes of change and human dimension implications. Global Planet Change 50:63-82. doi:10.1016/ j.gloplacha.2005.07.004

Firman T (2000) Rural to urban land conversion in Indonesia during boom and bust periods. Land Use Policy 17:13-20

Firman T (2009) The continuity and change in mega-urbanization in Indonesia: a survey of Jakarta-Bandung Region (JBR) development. Habitat Int 33:327-339. doi:10.1016/j.habitatint.2008.08.005

Harsolumakso AH (2001) Struktur geologi dan daerah genangan. Bull Geo 33:29-45

Horritt MS, Bates PD (2002) Evaluation of 1-D and 2-D numerical models for predicting river flood inundation. J Hydrol 268:87-99

Hutasoit LN (2001) Kemungkinan hubungan antara kompaksi alamiah dengan daerah genangan air di DKI Jakarta. Bull Geo 33:21-28

ICBR (2001) Atlas van het overstromingsgevaar en mogelijke schade bij extreem hoogwater van de Rijn international rhine commission (ICBR), Koblenz, Germany

IPCC (2007a) Climate Change 2007: impacts, adaptation and vulnerability. Contribution of working group II to the fourth assessment report of the intergovernmental panel on climate change. Cambridge University Press, Cambridge, UK

IPCC (2007b) Climate change 2007: the physical science basis. Contribution of working group I to the fourth assessment report of the intergovernmental panel on climate change. Cambridge University Press, Cambridge, UK

Klijn F, Baan PJA, De Bruijn KM, Kwadijk J (2007) Overstromingsrisico's in Nederland in een veranderend klimaat. WLIDelft hydraulics, Delft 
Kreibich H, Piroth K, Seifert I, Maiwald H, Kunert U, Schwarz J, Merz B, Thieken AH (2009) Is flow velocity a significant parameter in flood damage modeling? Nat Haz Earth Syst Sci 9:1679-1692

Madsen H, Jakobsen F (2004) Cyclone induced storm surge and flood forecasting in the northern Bay of Bengal. Coast Eng 51:277-296

Marfai MA, King L (2007) Monitoring land subsidence in Semarang, Indonesia. Env Geol 53:651-659. doi: 10.1007/s00254-007-0680-3

Marfai MA, King L (2008a) Potential vulnerability implications of coastal inundation due to sea level rise for the coastal zone of Semarang city, Indonesia. Environ Geo 54:1235-1245. doi:10.1007/s00254007-0906-4

Marfai MA, King L (2008b) Tidal inundation mapping under enhanced land subsidence in Semarang, Central Java Indonesia. Nat Hazards 44:93-109. doi:10.1007/s11069-007-9144-z,2008

Marfai MA, King L (2008c) The impact of tidal flooding on a coastal community in Semarang, Indonesia. Environmentalist 28:237-248

Mastin MC, Olsen TD (2002) Fifty-year storm-tide flood-inundation maps for Santa de Aqua, Honduras. USGS, Tacoma, USA

Meckel TA, Ten Brink US, Williams SJ (2007) Sediment compaction rates and subsidence in deltaic plains: numerical constraints and stratigraphic influences. Basin Res 19:19-31. doi:10.1111/j.13652117.2006.00310.x

Merz B, Kreibich H, Thieken A, Schmidtke R (2004) Estimation uncertainty of direct monetary flood damage to buildings. Nat Haz Earth Syst Sci 4:153-163

Merz B, Thieken AH, Gocht M (2007) Flood risk mapping at the local scale: concepts and challenges. In: Begum S, Stive MJF, Hall JW (eds) Flood risk management in Europe-innovation in policy and practice. Springer, Dordrecht, pp 231-251

Murdohardono D, Sudarsono U (1998) Land subsidence monitoring system in Jakarta. Proceedings of the symposium on Japan-Indonesia IDNDR project: volcanology, tectonics, flood and sediment hazards, Bandung, Indonesia, 21-23 September 1998, pp 243-256

Nicholls RJ (1995) Coastal megacities and climate change. Geo J 37:369-379

Nicholls RJ (2002) Analysis of global impacts of sea-level rise: a case study of flooding. Phys Chem Earth A/B/C 27:1455-1466. doi:10.1016/S1474-7065(02)00090-6

Nicholls RJ (2004) Coastal flooding and wetland loss in the 21st century: changes under the SRES climate and socio-economic scenarios. Global Environ Chang 14:69-89. doi:10.1016/j.gloenvcha.2003.10.007

Nicholls RJ, Wong PP, Burkett V, Codignotto J, Hay J, McLean R, Ragoonaden S, Woodroffe CD (2007) Coastal systems and low-lying areas. In: Parry ML, Canziani O, Palutikof JP, van der Linden P, Hanson CE (eds) Climate change 2007: impacts, adaptation and vulnerability. Contribution of working group II to the fourth assessment report of the intergovernmental panel on climate change. Cambridge University Press, Cambridge, UK, pp 315-357

Nicholls RJ, Hanson S, Herweijer C, Patmore N, Hallegatte S, Corfee-Morlot J, Château J, Muir-Wood R (2008) Ranking port cities with high exposure and vulnerability to climate extremes: exposure estimates. OECD environment working papers No. 1, ENV/WKP(2007). OECD, Paris, France, http://www.olis.oecd.org/olis/2007doc.nsf/linkto/env-wkp(2007)1. Accessed 25 December 2009

Peltier WR (1998) Postglacial variations in the level of the sea: implications for climate dynamics and solidearth geophysics. Rev Geophys 36:603-689

Penning-Rowsell E, Fordham M, Correia FN, Gardiner J, Green C, Hubert G, Ketteridge A-M, Klaus J, Parker D, Peerbolte B, Pflügner W, Reitano B, Rocha J, Sanchez-Arcilla A, MdG Saraiva, Schmidtke R, Torterotot J-P, Van der Veen A, Wierstra E, Wind H (1994) Flood hazard assessment, modeling and management: results from the EURO flood project. In: Penning-Rowsell E, Fordham M (eds) Floods across Europe: flood hazard assessment modeling and management. Middlesex University Press, London, pp 37-72

Penning-Rowsell EC, Johnson C, Tunstall SM, Tapsell S, Morris J, Chatterton J, Coker A, Green C (2003) The benefits of flood and coastal defense: techniques and data for 2003. Flood hazard research centre. Middlesex University, Middlesex, UK

Pribadi KS (2008) Climate change adaptation research in Indonesia. Asian Universities for environment and disaster management, 28-29 July 2008, Kyoto, Japan

Purvis MJ, Bates PD, Hayes CM (2008) A probabilistic methodology to estimate future coastal flood risk due to sea level rise. Coast Eng 55:1062-1073. doi:10.1016/j.coastaleng.2008.04.008

Rismianto D, Mak W (1993) Environmental aspects of groundwater extraction in DKI Jakarta: changing views. Proceedings of the 22nd annual convention of the Indonesian Association of Geologists, Bandung, Indonesia, 6-0 December 2009, pp 327-345 
Rosenzweig C, Solecki W (2001) Climate change and a global city; the potential consequences of climate variability and change-metro east coast. Report for the US global change program. Columbia Earth Institute, New York, USA

Shennan I (1993) Geographic information systems and future sea level rise. In: Warrick RA, Barrow EM, Wigley TML (eds) Climate and sea level change. Cambridge University Press, Cambridge, UK, pp 215-228

Thumerer T, Jones AP, Brown D (2000) A GIS based coastal management system for climate change associated flood risk assessment on the east coast of England. Int J Geo Inf Sci 14:265-281

Vanneuville W, Maddens R, Collard C, Bogaert P, De Maeyer P, Antrop M (2006) Impact op mens en economie t.g.v. overstromingen bekeken in het licht van wijzigende hydraulische condities, omgevingsfactoren en klimatologische omstandigheden. MIRA/2006/02. Universiteit Gent, Gent

Verburg PH, Veldkamp TA, Bouma J (1999) Land use change under conditions of high population pressure: the case of Java. Global Environ Chang 9:303-312. doi:10.1016/S0959-3780(99)00175-2

Ward PJ, Van Balen RT, Verstraeten G, Renssen H, Vandenberghe J (2009) The impact of land use and climate change on late Holocene and future suspended sediment yield of the Meuse catchment. Geomorphology 103:389-400. doi:10.1016/j.geomorph.2008.07.006

Wind HG, Nierop TM, de Blois CJ, de Kok JL (1999) Analysis of flood damages from the 1993 and 1995 Meuse flood. Water Resour Res 35(11):3459-3465

World Bank (2010) The costs to developing countries of adapting to climate change. New methods and estimates. The global report on the economics of adaptation to climate change study. The World Bank, Washington, DC 